\title{
Imaged based identification of colombian timbers using the xylotron: A proof of concept international partnership
}

\section{Identificación de maderas colombianas utilizando el Xylotron: Prueba de concepto de una colaboración internacional}

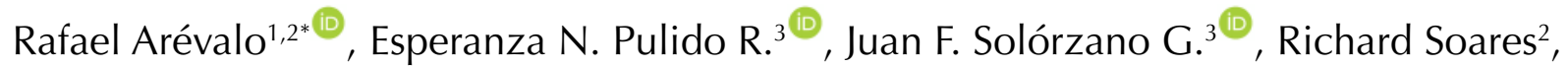 \\ Flavio Ruffinatto ${ }^{4}$, Prabu Ravindran ${ }^{1,2}$, and Alex C. Wiedenhoeft ${ }^{1,2,5,6,7}$
}

Arévalo, R., Pulido R., E. N., Solórzano G., J, F, Soares, R., Ruffinatto, F., Ravindran, P. and Windenhoeft, A. C. (2021). Imaged based identification of colombian timbers using the xylotron: A proof of concept international partnership. Colombia Forestal, 24(1), 5-16

Recepción: 20 de julio 2020

\begin{abstract}
Field deployable computer vision wood identification systems can be relevant in combating illegal logging in the real world. This work used 764 xylarium specimens from 84 taxa to develop an image data set to train a classifier and identify 14 commercial Colombian timbers. We took images of specimens from various xylaria outside Colombia, trained and evaluated an initial identification model and then collected additional images from a Colombian xylarium (BOFw) and incorporated these images to refine and produce a final model. The specimen classification accuracy of this final model was $\sim 97 \%$, which demonstrates that including local specimens can augment the accuracy and reliability of the XyloTron system. Our study demonstrates the first deployable computer vision model for wood identification in Colombia, which is developed on a timescale of months rather than years by leveraging on international cooperation.
\end{abstract}

Aprobación: 02 de noviembre 2020

We conclude that field testing and advanced forensic and machine learning training are the next logical steps.

Key words: Deep learning, Forensic wood anatomy, Machine Learning, Transfer learning, Wood identification.

\section{Resumen}

Sistemas de identificación automatizada de maderas pueden fortalecer la lucha contra el tráfico ilegal de maderas. Este trabajo utilizó 764 especímenes de xilotecas, correspondientes a 84 taxones, para desarrollar un modelo de identificación para 14 especies comerciales de Colombia. Se comenzó colectando imágenes de especímenes provenientes de xilotecas fuera de Colombia, que se utilizaron para entrenar y evaluar un modelo inicial. Se colectaron imágenes adicionales provenientes de una xiloteca Colombiana (BOFw), que se utilizaron para refinar y producir el modelo final. La capacidad de reconocimiento de

\footnotetext{
Department of Botany, University of Wisconsin, Madison, WI 53706, USA.

Center for Wood Anatomy Research, USDA Forest Service, Forest Products Laboratory, Madison, WI 53726, USA.

Facultad de Medio Ambiente y Recursos Naturales, Universidad Distrital Francisco Jose de Caldas, Bogotá D.C., Colombia.

DISAFA, University of Torino, Largo Paolo Braccini 2, 10095 Grugliasco (TO), Italy.

Department of Forestry and Natural Resources, Purdue University, USA.

Departamento de Ciências Biolôgicas (Botânica), Universidade Estadual Paulista - Botucatu, Brasil.

Department of Sustainable Bioproducts, Mississippi State University, Starkville, MS, USA.

Correspondencia: arevaloburba@wisc.edu
} 
este modelo fue del $\sim 97 \%$, demostrando que incluir muestras locales aumenta la precisión y confiabilidad del sistema [XyloTron]. Este estudio presenta el primer modelo de vision computarizada para identificación de maderas en Colombia, desarrollado en una escala de tiempo corta y bajo cooperación internacional. Concluimos que pruebas en campo y capacitación forense y en aprendizaje automatizado, son los siguientes pasos lógicos a seguir.

Palabras clave: Anatomía forense de madera, Aprendizaje profundo, Aprendizaje automatizado, Identificación de madera, Transferencia de aprendizaje.

\section{INTRODUCTION}

It has been estimated that more than $40 \%$ of wood production in Colombia emanates from illegal sources (WWF-Colombia, 2013). In a country where $52 \%$ of the area is occupied by natural forests and in which illegal logging is one of the principal drivers of deforestation (IDEAM, 2020), extraction and commercialization of wood generates a significant environmental and socioeconomic impact and is an explicit threat to biodiversity through habitat loss. To guarantee legality of forest products supply chain, it is necessary to obtain official permits and authorizations from Regional Environmental Authorities that enforce national standards that governing the use, management, transport and sale of forest products. In addition, Colombia has been developing wood identification tools for commercial timbers (Covima, 2020; Especies Maderables, 2016; López Camacho et al., 2014; WWF-Colombia, 2013) and implementing policies and initiatives (e.g. Operation Artemisa) that would ensure that forests are protected and wood and wood-derived products are legally sourced. Compliance with and enforcement of international and local laws for legal wood products depend, in part, on the rapid and reliable identification of wood to validate claims of legality (Wiedenhoeft et al., 2019). Such technical or forensic expertise in turn hinges on the design, validation and deployment of robust scientific wood forensic pipelines to identify timber and combat fraud throughout the supply chain (Lowe et al., 2016).

In a typical scenario, when environmental authorities inspect wood in trade, they evaluate a shipment based on a reported commercial or common name used in the region. Unlawful operators typically falsify paperwork, claiming that the wood in a shipment is of lower value species when, in reality, the shipment contains higher-value/endangered and (sometimes) superficially similar species. The only way to detect such a fraud is to inspect a shipment and make provisional identification of the wood to determine if it is consistent with information provided on the paperwork. To make the greatest impact in preventing illegal trade, these inspections of wood must take place in uncontrolled environmental conditions (i.e. at the point of harvest, in a lumber mill and at the port of shipment) in a matter of seconds to establish probable cause for seizure, detention and further forensic analyses, or release the consignment into trade as compliant. If possible, specimens from a detained consignment should be subjected to further forensic analysis in a laboratory using genetic/microscopy/spectral techniques to enable a legally valid identification (Dormontt et al., 2015).

In Colombia, as in most of the world, if any field screening of timber is undertaken at all, then it is human-based, with customs, environmental and police authorities requiring significant training and regular practice in the use of traditional wood anatomical identification methods to achieve a useful level of proficiency. Unfortunately, there is a significant dearth of such human expertise and lack of infrastructure in most control and surveillance posts to perform accurate and reliable identifications. Consequently, field screening of timber more often relies on subjective evaluation of few 
and often poorly defined characteristics of wood, such as color/appearance, grain/texture, luster and odor-with no reference to anatomical features of the wood. The lack of sufficient human expertise compared to the demand for timber screening is a major bottleneck in ensuring legal timber trade and has established the clear need for reliable field-deployable wood identification technologies (Wiedenhoeft et al., 2019).

Computer vision-based wood identification is an attractive technology for the development of quick, reliable and field-deployable tools for field screening of wood (de Andrade et al., 2020; Filho et al., 2014; Hermanson and Wiedenhoeft, 2011; Khalid et al., 2008; Ravindran et al., 2018; Souza et al., 2020). The availability of affordable, open source, field-deployable, field tested and image-based wood identification platforms (Ravindran et al., 2020) with identification accuracies that match or exceed those of other expensive technologies (Ravindran \& Wiedenhoeft, 2020) have further established the potential of computer vision-based systems as effective and scalable field screening technologies, especially in human-mediated contexts.

In this project, we trained a macroscopic image-based identification model of fourteen commercially important Colombian timbers for use in conjunction with the XyloTron system (Ravindran et al., 2020). Our data collection and model development was done as part of a World Wildlife Fund (WWF)-funded international partnership to develop new technology, knowledge and methodologies that can support capacity building for timber tracking and timber forensics in the Colombian timber market. The pilot study described here yields valuable insights into how an international cooperation can develop a deployable solution to a real-world problem on a timescale of months rather than years. To the best of our knowledge, this is the first report on using a computer vision/ machine learning model for wood identification in Colombia.

\section{MATERIALS AND METHODS}

The transverse surface of specimens from 14 genera (84 taxa, 764 specimens) from xylaria at USDA Forest Products Laboratory (MADw and SJRw), Wood Laboratory of the Universidad Distrital Francisco José de Caldas (BOFw), Tervuren wood collection (Tw) and Xiloteca Dr. Calvino Mainieri, Instituto de Pesquisas Tecnológicas do Estado de São Paulo (BCTw) were polished using progressively finer-grit sandpapers (240, 400, 600, 800, 1000 and 1500) using compressed air and adhesive tape to, as much as possible, remove dust from the cell lumina between each grit. Imaging of polished surfaces was done using the XyloTron (Ravindran et al., 2020), a macroscopic imaging and computer vision system was used for the wood identification. Each image (with dimensions $2048 \times 2048$ pixels) shows $6.35 \times 6.35 \mathrm{~mm}$ of tissue. Details of the selected taxa and image dataset are provided in table 1 and Appendix 1, respectively. Species level identification for the selected taxa was not required (and not possible), hence the 4108 images from the 84 taxa were categorized into 14 genus-level classes for machine learning purposes. The image dataset was separated into a training and testing set, such that $80 \%$ of the specimens in the dataset contributed images to the training data only, while the remaining $20 \%$ of specimens contributed images to the testing set only. The mutual exclusivity between the training and testing data at the specimen level (as opposed to just the image level) prevents the neural network from learning features to identify the individual specimens, thereby making accuracy of the trained model more informative of its real-world wood identification performance.

We trained and evaluated a convolutional neural network $(\mathrm{CNN})$ that comprise a ResNet (He et al., 2016) backbone pre-trained on the ImageNet dataset (Russakovsky et al., 2015) with a custom classifier head using transfer learning (Pan \& Yang, 2010) to classify images of the transverse surfaces 
of wood into 14 genus-level classes. Random patches (with dimensions $2048 \times 768$ pixels) were extracted from the training set images, down-sampled by a factor of 4 and inputted in the network in mini-batches of size 16. Our data augmentation strategy included horizontal and vertical reflections, rotations and cutout (Devries \& Taylor, 2017). The training methodology and hyperparameter settings used were similar to those used in prior works (Ravindran et al., 2019; Ravindran et al., 2020; Ravindran \& Wiedenhoeft, 2020).
To evaluate the specimen classification accuracy of the trained $\mathrm{CNN}$, we computed the predicted label of a specimen as the majority label from the predictions on its individual images (Ravindran \& Wiedenhoeft, 2020). If, for instance, a specimen of Cedrelinga has 13 images in the test data set and 7 of the images are predicted as Cedrelinga and 6 are predicted as Parkia, the label prediction for the specimen will be Cedrelinga. To arrive at an overall accuracy, the number of correctly predicted specimens was divided by the total number of specimens.

Table1. List of taxa included in this study

\begin{tabular}{|c|c|c|}
\hline Genus & Species & Synonyms \\
\hline Campnosperma & C. panamense Standl. & \\
\hline \multirow{2}{*}{ Cariniana } & C. domestica (Mart.) Miers & \\
\hline & C. pyriformis Miers & \\
\hline Cedrela & C. odorata L. & \\
\hline Cedrelinga & C. cateniformis (Duce) Ducke & \\
\hline Erisma & E. uncinatum Warm. & \\
\hline \multirow[t]{9}{*}{ Eschweilera } & E. albiflora (DC.) Miers & E. pachysepala \\
\hline & E. amazonica R. Knuth & \\
\hline & E. cf. atropetiolata S.A.Mori & \\
\hline & E. coriacea (DC.) S.A.Mori & \\
\hline & E. juruensis R. Knuth & \\
\hline & E. micrantha (O.Berg.) Miers & E. polyantha \\
\hline & E. parvifolia Mart. ex DC. & E. krukovii \\
\hline & E. pedicellata (Rich.) S.A.Mori & E. longipes \\
\hline & E. rhododendrifolia (R.Knuth) A.C.Sm. & \\
\hline Humiriastrum & H. procerum (Little) Cuatrec. & \\
\hline \multirow[t]{10}{*}{ Ocotea } & O. aciphylla (Nees \& Mart.) Mez & O. costulata \\
\hline & O. canaliculata (Rich.) Mez & \\
\hline & O. caracasana (Nees) Mez & \\
\hline & O. cymbarum Kunth & O. barcellensis \\
\hline & O. diospyrifolia (Meisn.) Mez & \\
\hline & O. fasciculata (Nees) Mez & \\
\hline & O. floribunda (Sw.) Mez & \\
\hline & O. fragrantissima Ducke & \\
\hline & O. glomerata (Nees) Mez & \\
\hline & O. longifolia Kunth & \\
\hline \multirow[t]{3}{*}{ Parkia } & P. multijuga Benth. & \\
\hline & P. paraensis Ducke & \\
\hline & P. velutina Benoist & \\
\hline \multirow[t]{5}{*}{ Pouteria } & P. cuspidata (A.DC.) Baehni & \\
\hline & P. guianensis Aubl. & \\
\hline & P. hispida Eyma & P. solimoesensis \\
\hline & P. macrocarpa (Mart.) D.Dietr. & \\
\hline & P. macrophylla (Lam.) Eyma & \\
\hline
\end{tabular}


Imaged based identification of colombian timbers using the xylotron: A proof of concept international partnership

Arévalo, R., Pulido R., E. N., Solórzano G., J, F, Soares, R., Ruffinatto, F., Ravindran, P. and Windenhoeft, A. C.

\begin{tabular}{|c|c|c|}
\hline Genus & Species & Synonyms \\
\hline \multirow{7}{*}{ Qualea } & P. torta (Mart.) Radlk. & \multirow{7}{*}{ P. gutta } \\
\hline & P. torta subsp. glabra T.D.Penn & \\
\hline & P. trilocularis Cronquist & \\
\hline & Q. acuminata Spruce ex Warm. & \\
\hline & Q. albiflora Warm. & \\
\hline & Q. paraensis Ducke & \\
\hline & Q. wittrockii Malme & \\
\hline Rhizophora & R. mang/e L. & \\
\hline \multirow{21}{*}{ Virola } & V. bicuhyba (Schott) Warb. & \\
\hline & V. calophylla (Spruce) Warb. & \\
\hline & V. calophylloidea Markgr. & \\
\hline & V. carinata (Spruce ex Benth.) Warb. & \\
\hline & V. elongata (Benth.) Warb. & \\
\hline & V. flexuosa A.C. Sm. & \\
\hline & V. gardneri (A.DC.) Warb. & \\
\hline & V. guatemalensis (Hemsl.) Warb. & \\
\hline & V. koschnyi Warb. & \\
\hline & V. loretensis A.C. Sm. & \\
\hline & V. macrocarpa A.C. Sm. & \\
\hline & V. michelii Heckel & V. melinonii \\
\hline & V. mollissima (Poepp. ex A.DC.) Warb. & \\
\hline & V. multicostata Ducke & \\
\hline & V. multinervia Ducke & \\
\hline & V. officinalis Warb. & \\
\hline & V. oleifera (Schott) A.C.Sm. & Bicuiba oleifera \\
\hline & V. pavonis (A.DC.) A.C.Sm. & \\
\hline & V. sebifera Aubl. & \\
\hline & V. surinamensis (Rol. ex Rottb.) Warb. & Myristica gracilis \\
\hline & V. venosa (Benth.) Warb. & \\
\hline \multirow[t]{19}{*}{ Vochysia } & V. cayennensis Warm. & \\
\hline & V. cf. ferruginea Mart. & \\
\hline & V. densiflora Spruce & \\
\hline & V. ferruginea Mart. & \\
\hline & V. floribunda Mart. & \\
\hline & V. guatemalensis Donn.Sm. & V. hondurensis \\
\hline & V. guianensis Aubl. & V. melinonii \\
\hline & V. inundata Ducke & \\
\hline & V. laurifolia Warm. & \\
\hline & V. maxima Ducke & \\
\hline & V. obidensis (Huber ex Ducke) Ducke & \\
\hline & V. obscura Warm. & \\
\hline & V. rufescens W.A. Rodrigues & \\
\hline & V. speciosa Warm. & \\
\hline & V. splendens Spruce ex Warm. & \\
\hline & V. surinamensis Stafleu & \\
\hline & V. thyrsoidea Pohl & \\
\hline & V. tomentosa (G.Mey) DC. & \\
\hline & V. vismiifolia Spruce ex Warm. & \\
\hline
\end{tabular}




\section{RESULTS}

The specimen classification accuracy was $97.3 \%$. The specimen confusion matrix is shown in figure 1 , and a total of four specimens were misclassified. The XyloTron, without any optimization for computational performance, requires approximately 2-3 seconds of computational time on a consumer laptop for each image identification, when used in the field.

\section{DISCUSSION}

This project developed a highly accurate, machine-learning based wood identification model that can/or should be used to improve timber trade in Colombia. This goal, in the span of less than one year, was established with thanks to a strong international collaboration and partnership. Working together, we were able to build a pilot model in USA, test it in Colombia, improve it with additional data from Colombia's wood collections and then develop the final model we present here.

The accuracy of the model presented here (figure 1) greatly exceeds the average accuracy and reliability of wood identification experts working in a laboratory setting, as shown in a recent survey conducted in USA (Wiedenhoeft et al., 2019). We are not aware of any country with trained field personnel able to separate these woods with few misclassifications. Only three class-pairs of woods were confused: Cedrelinga-as-Parkia, Qualea-as-Vochysia, and Virola-as-Ocotea.

Cedrelinga and Parkia (figure 2, top) have similar tangential vessel diameter and vessel density and both have vasicentric to lozenge aliform parenchyma. It is interesting to note that a model incorporating UV illumination (Ravindran et al., 2020) would separate this class-pair, since Cedrelinga heartwood is fluorescent and Parkia is not. Qualea and Vochysia (figure 2, middle) have

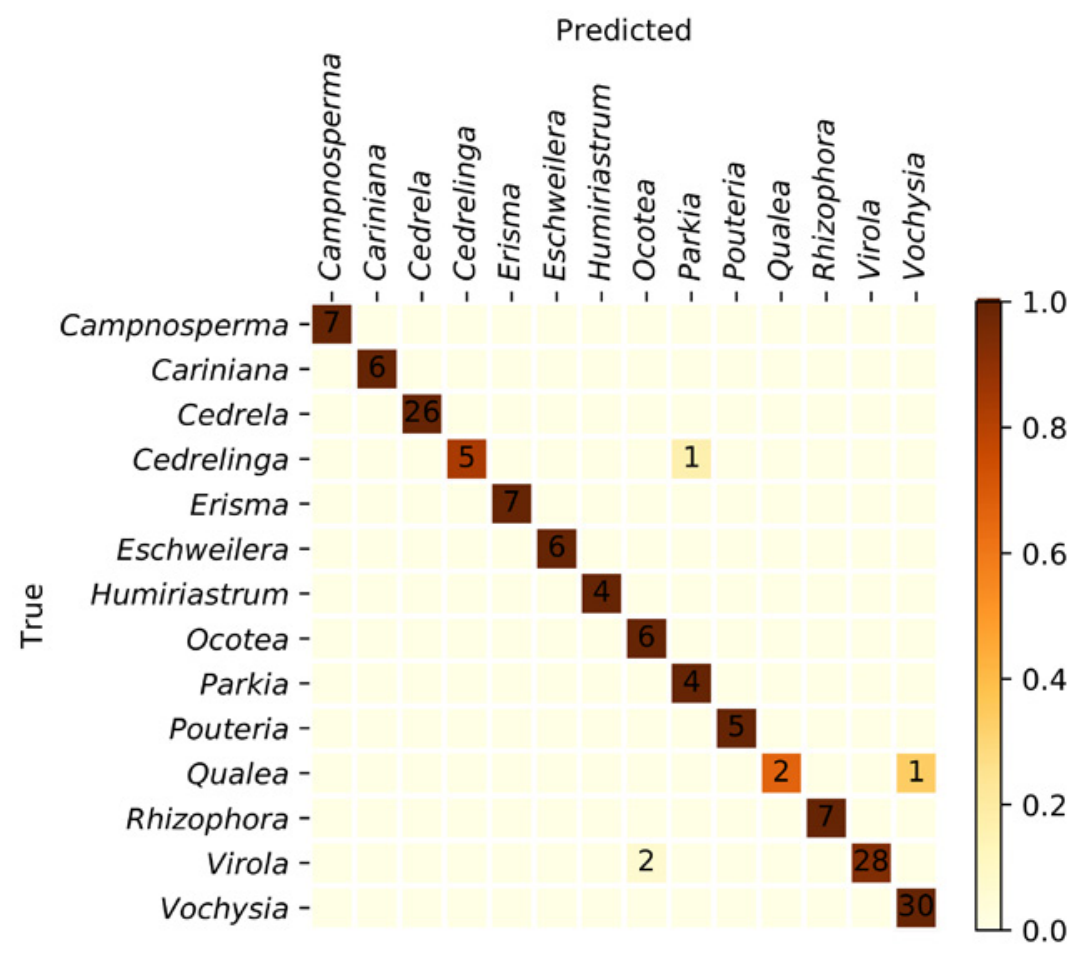

Figure 1. Specimen confusion matrix for the XyloTron wood identification model of 14 Colombian timbers. Overall accuracy was $97.3 \%$. Four specimens were misclassified within three different class-pairs. 
macroscopically similar ray widths and abundance, as well as lozenge aliform to short confluent parenchyma and indeed even in the laboratory. Moreover, using full light microscopic identification, it can be challenging to separate these genera (Quirk, 1980). Virola and Ocotea (Figure 2, bottom) are both somewhat macroscopically similar woods, without any evident characters from the transverse surface to separate the two. If tangential surfaces were added to XyloTron models, the separation of this class-pair would presumably become certain, since Virola has tanniferous tubes in the

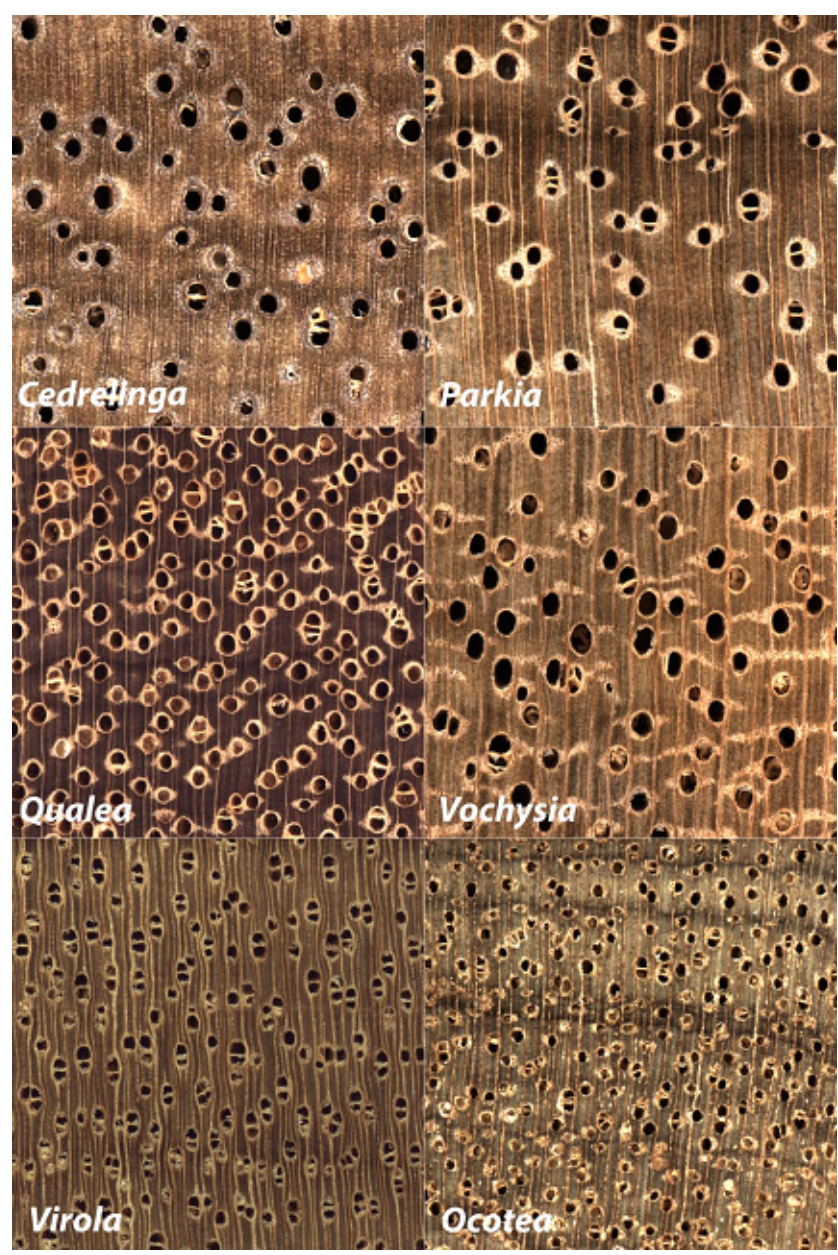

Figure 2. XyloTron images of the pair (top, middle and bottom) of true class (left) and predicted class (right) for each of the three class-pair misidentifications in the model.

Note that, for each class-pair, the wood anatomical patterns seen with the XyloTron are similar. rays that appear as dark dots on the tangential surface, whereas Ocotea lacks them.

To make better use of the advances from this project, the next logical step would be to conduct a robust field test of the model in Colombia-at markets, lumber yards and at other points of trade control. This would necessitate validation of the XyloTron's field results by expert human evaluators, ideally by forensic wood identification in the laboratory. It would also be a powerful capacity building exercise for several Colombian colleagues to make a research visit to the Center for Wood Anatomy Research (CWAR) in order to engage in a robust program of advanced training in wood anatomy and machine learning, which are the two sets of expertise needed to adopt and adapt the XyloTron for the Colombian context. With field performance data and increased in-country knowledge of the design, function and machine learning model used by the XyloTron, we could determine the most efficient way to use resources to expand the breadth of Colombian taxa identifiable by the XyloTron.

\section{CONCLUSIONS}

With the right partnership, it is possible to develop, implement and complete a machine vision wood identification project with the potential to strengthen control mechanisms for trade and commercialization of wood in the country of origin and within a timescale of months rather than years. This is the first report of such an efficient program of work with a highly accurate machine vision wood identification model as a result. Our identification model had in silico accuracy greater than $97 \%$, an accuracy far higher than any, but by the best forensic experts in a laboratory setting.

Field testing of the model and verification of the model's results by laboratory testing is a critical next step, ideally followed by a research sabbatical in CWAR to expand knowledge on XyloTron operation and development. With this enhanced 
capacity, it will be possible to establish best practices for how best to expand the breadth of Colombian woods identifiable by the XyloTron.

\section{ACKNOWLEDGMENTS}

This publication resulted from research supported by the World Wildlife Fund (WWF) through their WWF-US Innovation Funds. Special thanks to A. Smith at WWF-US and M. Pacheco at WWF-Colombia for their support throughout the different phases of this project. We thank the anonymous reviewers whose comments helped to improve and clarify this manuscript.

\section{CONTRIBUTION BY AUTHOR}

R.A. and A.C.W. initiated the project. P.R. developed the machine learning analyses. A.C.W., R.S. and R.A. conducted the forensic analysis of the wood and established the scope of the identification models. E.N.P.R. and J.F.S.G. collected images from additional/new Colombian specimens. R.A., R.S., F.R., and J.F.S.G. prepared samples for imaging and imaged the specimens. A.C.W. curated the collected data. P.R. and A.C.W. conducted data analysis and synthesis. R.A., A.C.W., and P.R. wrote the paper. All authors read, contributed, and approved the final manuscript.

\section{REFERENCES}

Covima. (2020). Minambiente. (V.2.9.4) [mobile software]

de Andrade, B.G., Basso, V.M. \& de Figueiredo Latorraca, J.V. (2020). Machine vision for field-level wood identification. IAWA Journal, 1-18. https://doi.org/10.1163/22941932-bja10001

Devries, T. \& Taylor, G.W. (2017). Improved regularization of convolutional neural networks with cutout. arXiv e-prints, abs/1708.04552.
Dormontt, E.E., Boner, M., Braun, B., Breulmann, G., Degen, B., Espinoza, E., Gardner, S., Guillery, P., Hermanson, J.C., Koch, G., Lee, S.L., Kanashiro, M., Rimbawanto, A., Thomas, D., Wiedenhoeft, A.C., Yin, Y., Zahnen, J. \& Lowe, A.J. (2015). Forensic timber identification: It's time to integrate disciplines to combat illegal logging. Biological Conservation, 191, 790-798.

Especies Maderables 2. (2016). Kudos Ltda. (V.0.1.3) [mobile software]

Filho P.L.P., Oliveira L.S., Nisgoski S. \& Britto A.S. (2014). Forest species recognition using macroscopic images. Machine Vision and Applications, 25, 1019-1031. https://doi.org/10.1007/s00138-014-0592-7

He K., Zhang X., Ren S. \& Sun J. (2016). Deep residual learning for image recognition. En: Proceedings of the IEEE Conference on Computer Vision and Pattern Recognition (CVPR), pp. 770-778.

Hermanson J.C. \& Wiedenhoeft A.C. (2011). A brief review of machine vision in the context of automated wood identification systems. IAWA Journal, 32(2), 233-250.

IDEAM. (2020). Resultados de monitoreo de deforestación, 2019. Retrieved from: http://www.ideam.gov.co/documents/10182/10541 3996/presentacionbalancedeforestacion2019/7c9323fcd0a1-4c95-b1a1-1892b162c067

Khalid M., Lee E.L.Y., Yusof R. \& Nadaraj M. (2008). Design of an intelligent wood species recognition system. International Journal of Simulation System, Science and Technology, 9(3), 9-19.

López Camacho R., Pulido Rodríguez E.N., González Martínez R.O., Nieto Vargas J.E. \& Vásquez M.Y. (2014). Maderas. Especies comercializadas en el territorio CAR. Guía para su identificación. Bogotá D.C.: Editorial Universidad Distrital Francisco José de Caldas.

Lowe A.J., Dormontt E.E., Bowie M.J., Degen B., Gardner S., Thomas D., Clarke C., Rimbawanto A., Wiedenhoeft A.C., Yin Y. \& Sasaki N. (2016). Opportunities for improved transparency in the timber trade through scientific verification. BioScience, 66(11), 990-998. https://doi.org/10.1093/biosci/biw129 
Pan S.J. \& Yang Q. (2010). A survey on transfer learning. IEEE Transactions on Knowledge and Data Engineering, 22(10), 1345-1359.

Quirk J.T. (1980). Wood anatomy of the Vochysiaceae. IAWA Bulletin, 1(4), 172-179.

Ravindran P. \& Wiedenhoeft A.C. (2020) Comparison of two forensic wood identification technologies for ten Meliaceae woods: computer vision versus mass spectrometry. Wood Science and Technology, 54(5), 1139-1150. https://doi.org/10.1007/s00226-020-01178-1

Ravindran P., Costa A., Soares R. \& Wiedenhoeft A.C. (2018). Classification of CITES-listed and other neotropical Meliaceae wood images using convolutional neural networks. Plant Methods, 14, 25. https://doi.org/10.1186/s13007-018-0292-9

Ravindran P., Ebanyenle E., Ebeheakey A.A., Abban K.B., Lambog O., Soares R., Costa A. \& Wiedenhoeft A.C. (2019). Image based identification of Ghanaian timbers using the XyloTron: Opportunities, risks and challenges. En: M. De-Arteaga, T. Afonja, A. Coston (eds.). Proceedings of NeurlPS 2019 Workshop on Machine Learning for the Developing World: Challenges and Risks of MLAD. arXiv:2001.00249.
Ravindran P., Thompson B.J., Soares R.K. \&Wiedenhoeft A.C. (2020) The XyloTron: Flexible, open-source, image-based macroscopic field identification of wood products. Frontiers in Plant Science, 11, 1015. https://doi.org/10.3389/fpls.2020.01015

Russakovsky O., Deng J., Su H., Krause J., Satheesh S., Ma S., Huang Z., Karpathy A., Khosla A., Bernstein M., Berg A.C. \& Fei-Fei L. (2015). ImageNet large scale visual recognition challenge. International Journal of Computer Vision, 115(3), 211-252.

Souza D.V., Santos J.X., Vieira H.C., Naide T.L., Nisgoski S. \& Oliveira L.E.S. (2020). An automatic recognition system of Brazilian flora species based on textural features of macroscopic images of wood. Wood Science and Technology, 54, 1065-1090.

Wiedenhoeft A.C., Simeone J., Smith A., Parker-Forney M., Soares R., Fishman A. (2019). Fraud and misrepresentation in retail forest products exceeds U. S. forensic wood science capacity. PLoS ONE, 14(7), e0219917.

WWF-Colombia-Programa Subregional Amazonas Norte \& Chocó Darién. (2013). Maderas de Colombia. Retrieved from: www.wwf.org.co/?213040/Maderas-de-Colombia 
Appendix 1. List of taxa included in this study with collection and voucher information: taxon [synonym] - xylarium accessions. Xylarium acronyms: BCTw = Xiloteca Dr. Calvino Mainieri, Instituto de Pesquisas Tecnológicas do Estado de São Paulo S.A. - IPT, Sao Paulo, Brazil; FORIGw = Forestry Research Institute of Ghana, Kumasi, Ghana; MADw, SJRw = Forest Products Laboratory Wood Collection and Samuel J. Record Memorial Wood Collection, USDA Forest Service, Forest Products Laboratory, Madison, USA; Tw = Tervuren Xylarium, Royal Museum for Central Africa, Tervuren, Belgium; BOFw = Laboratorio de Maderas, Universidad Distrital Francisco José de Caldas (UDBC), Bogotá D.C., Colombia.

Campnosperma panamense Standl._BCTw:19002; MADw:37946, 55237; BOFW:3463, 3464, 3465, 3466, 3467, 3476, 3477, 3478, 3479, 3503, 3504, 3505, 3506, 3507, 3508, 3509, 3510, 3511, 3515, 3519, 3521, 3522, 3525, 3528, 3529, 11346, 18466, 24842, 37946; SJRw:10500, 42731, 42964, 51609, 55237, 6770, 6924. Cariniana domestica (Mart.) Miers-MADw:18729. Cariniana pyriformis MiersMADw:3911; MADw:10618, 21093, 30792, 3910, 3911, 3915; SJRw:1602, 3968, 414, 500; Tw:30211; BOFW:1082, 1500, 3480, 3481, 3482, 3483, 3484, 3485, 3486, 3487, 3488, 3489, 3490, 3516, 3523, 3526, 3527. Cedrela odorata L._BCTw:10483, 11494, 12456, 13474, 15280, 16144, 16639, 16855, 17002, 17655, 18055, 20019, 5543, 8220, 9552, 9555; FORIGw:24; MADw:10357, 10615, 10773, 10901, 11062, 12357, 13785, 14786, 15031, 16010, 17649, 18448, 19052, 19355, 19685, 20551, 20564, 20742, 21569, 22016, 22229, 23066, 23116, 23209, 26495, 26506, 33880, 3591, 42297, 42711, 42726, 7145; SJRw:10658, 10834, 10902, 11248, 12438, 1308, 15676, 15871, 1928, 1929, 20074, 2051, 2167, 23951, 2942, 3035, 3134, 3277, 329, 32935, 33914, 34671, 34734, 349, 35041, 35164, 35994, 36522, 37954, 38455, 39509, 39628, 40783, 40907, 410, 411, 41170, 43372, 43613, 4378, 4763, 4765, 4780, 47899, 47902, 47904, 4993, 5109, 53579, 53611, 53763, 55162, 5947, 6661, 6835, 727, 7485, 7622, 7648, 7937, 825, 8455, 8901, 8995, 9527, 9614; BOFW:3468, 3469, 3470, 3471, 3472, 3473, 3474, 3475, 3491, 3492, 3493, 3494, 3495, 3496, 3497, 3524. Cedrelinga cateniformis (Duce) Ducke-BCTw:10938, 12515, 13374, 13485, 13583, 13916, 15074, 19683, 9944; MADw:13596, 14091, 22148, 22362, 25406, 37949, 46450, 46463; SJRw:20715, 37813, 37840, 37843, 37845, 43389, 43390, 43423, 48679, 49373, 52841; Tw:14000; BOFW:3501, 3514. Erisma uncinatum Warm.BCTw:10074, 12514, 12778, 13129, 13396, 13431, 13481, 14015, 14153, 14154, 14155, 16038, 16542, 18639, 18968, 20028, 2123, 82, 8411; MADw:19108, 19282, 19285, 19294, 19574, 21481, 37956; SJRw:39610, 50577, 50932, 51781, 55661, 55686; Tw:20635; BOFW:3498, 3499, 3500. Eschweilera. albiflora (DC.) Miers [E. pachysepala]—MADw:12834; SJRW:37094. Eschweilera amazonica R. KnuthMADw:48836. Eschweilera cf. atropetiolata S.A.Mori-MADw:32630. Eschweilera coriacea (DC.) S.A.Mori-MADw:19657, 30859, 30860, 30861, 30862, 30863; SJRw:35450, 36645, 36688, 45742, 45743, 45744. Eschweilera juruensis R. Knuth-MADw:12460, 12497, 18646, 18771, 18776. Eschweilara micrantha (O.Berg.) Miers [E. polyantha] - MADw:12447, 12453, 30879; SJRw:36630, 36637. Eschweilara parvifolia Mart. ex DC. [E. krukovii]—MADw:12337, 12366, 18574, 18932; SJRw:36491, 36534. Eschweilera pedicellata (Rich.) S.A.Mori [E. longipes]-MADW:45232. Eschweilera rhododendrifolia (R.Knuth) A.C.Sm- MADW:30880. Humiriastrum procerum (Little) Cuatrec.-BCTw:18508; MADw:10373, 10391, 10392, 17586, 22103; SJRw:40923, 40941, 40942, 43073, 43153, 4315301; BOFW:3517. Ocotea aciphylla (Nees \& Mart.) Mez [O. costulata]_BCTw:16386, 11489, 16987; MADw:42778, 43348, 12552, 12683, 12813, 23414, 31112; SJRw:21617, 23632, 36752, 36913, 37067. Ocotea canaliculata (Rich.) Mez-BCTw:12523; MADw:311041. Ocotea caracasana (Nees) Mez-BCTw:9721. Ocotea cymbarum Kunth [O. barcellensis]—BCTw:13827; MADw:13171, 14052, 
2520. Ocotea diospyrifolia (Meisn.) Mez-BCTw:12157. Ocotea fasciculata (Nees) MezBCTw:13818. Ocotea floribunda (Sw.) Mez-BCTW:7820. Ocotea fragrantissima Ducke-BCTw:12510, 14121; MADw:13388, 31120; SJRw:31952. Ocotea glomerata (Nees) Mez-BCTw:16406. Ocotea longifolia Kunth-MADw:45198, 48726. Parkia multijuga Benth-BCTw:10829, 11470, 12382, 13797; MADw:12417, 48781; SJRW:21333, 22759, 36595; Tw:34659; BOFW:1489. Parkia paraensis DuckeBCTw:14095, 14096, 14097, 17236, 17245, 17254. Parkia velutina Benoist-BCTw:16356; MADw:31528, 46452. Pouteria cuspidata (A.DC.) Baehni-MADw:43378, 47594, 47596. Pouteria guianensis AublBCTw:7821, 8952; MADw:20483, 21523, 23587, 23679. Pouteria hispida Eyma [P. solimoesensis] MADw:32128, 32221. Pouteria macrocarpa (Mart.) D.Dietr.-BCTw:10162, 6573. Pouteria macrophylla (Lam.) Eyma-BCTw:10045; MADw:5711, 6597, 7669. Pouteria torta (Mart.) Radlk.—MADw:12473, 12584, 32871. Pouteria torta subsp. glabra T.D.Penn [P. gutta]-MADw:2354, 23637, 32875. Pouteria trilocularis Cronquist-MADw:18697, 18716, 19022, 19040, 23674, 31747. Qualea acuminata Spruce ex Warm.-MADw:12846, 19280; SJRw:37111; BOFW:3451. Qualea albiflora Warm.—MADw:12133, 19281, 19559, 19620, 21417. Qualea paraensis Ducke-MADw:19263; SJRw:22737, 36735, 40096. Qualea wittrockii Malme-MADw:23384; SJRw:16789. Rhizophora mangle L.-MADw:10364, 10365, 10374, 10375, 10607, 11352, 13200, 13825, 22561, 24779, 33901, 36612, 7388; SJRw:10806, 12295, 1261, 16627, 17167, 19583, 1997, 21524, 22531, 37881, 40914, 40915, 40924, 40925, 42990, 46830, 55617, 55619, 5970, 6860, 8033, 9609; BOFW:3512, 3513, 3518. Virola bicuhyba (Schott) Warb.BCTw:11622, 2640, 3901, 4633, 6067. Virola calophylla (Spruce) Warb.-SJRw:17504. Virola calophyIloidea Markgr._BCTw:13758; SJRw:36951. Virola carinata (Spruce ex Benth.) Warb.—BCTw:16334; SJRw:37114. Virola elongata (Benth.) Warb.—BCTw:13759, 16315; MADw:34033; SJRw:17937, 17946, 17968, 18020, 18040, 22069, 35591, 35639, 35760, 36573, 36778, 36947, 43203. Virola flexuosa A.C. Sm._SJRw:36850. Virola gardneri (A.DC.) Warb._BCTw:12008, 13666; SJRw:3256, 3504, 3948. Virola guatemalensis (Hemsl.) Warb._SJRw:10659. Virola koschnyi Warb._MADw:34049, 7374; SJRw:13289, 21477, 35025, 36392, 3679, 43478, 47889, 7604, 7801, 8829, 8838. Virola loretensis A.C. Sm.SJRw:18155, 18212, 34139. Virola macrocarpa A.C. Sm.-SJRw:43245. Virola michelii Heckel [V. melinonii]—SJRw:32900, 47632, 47633, 47637; BCTw:16628, 16722. Virola molissima (Poepp. ex A.DC.) Warb.-SJRw:18098. Virola multicostata Ducke-BCTw:16319; SJRw:36919. Virola multinervia Ducke-BCTw:16529; SJRw:21359. Virola officinalis Warb.-SJRw:18463. Virola oleifera (Schott) A.C.Sm. [Bicuiba oleifera]-SJRw:1945, 36061, 4708, 674. Virola pavonis (A.DC.) A.C.Sm.—BCTw:13749; SJRw:37121. Virola sebifera Aubl.—BCTw:13752, 16613, 17003; MADw:37900; SJRw:12281, 23889, 39680, 39936, 40831, 41178, 42820, 43461, 43736, 45178, 45179, 455, 46503, 51682, 6825. Virola surinamensis (Rol. ex Rottb.) Warb. [Myristica gracilis]—BCTw:16557, 16925, 5547; SJRw:10174, 1251, 21126, 21127, 32869, 35522, 41119, 41427, 44167, 45793, 47573, 50921, 55545, 23888 Tw:10985;. Virola venosa (Benth.) Warb.—SJRw:36989. Virola sp.—BCTw:10874, 10877, 11213, 11239, 11466, 11614, 11615, 11973, 12801, 16289, 19631, 2898, 2914, 3273, 3505, 3610, 3615, 4079, 4744, 4794, 4969, 586, 6855, 6858, 7065, 9103, 9459, 9909; SJRw:15639, 18065, 1820, 18500, 20091, 2682, 36187, 38221, 38222, 43006, 43318, 43396, 45425, 47684, 52409, 6917. Vochysia cayennensis Warm.BCTw:12771. Vochysia cf. ferruginea Mart.-MADw:14011. Vochysia densiflora SpruceBCTw:12773. Vochysia ferruginea Mart.-BCTw:16159, 16644, 17787; MADw:17553, 17567, 18469, 23086, 23087, 23109, 23390, 23391, 23393, 23394, 32441, 37902, 37903, 37904, 42299, 5740; SJRw:13269, 35585, 35705, 41990, 42965, 43017, 43139, 43219, 43458, 43462, 46818, 50980, 53826, 55240. Vochysia floribunda Mart.—BCTw:325; MADw:23392. Vochysia guatemalensis Donn.Sm. [V. 
hondurensis]-BCTw:2049; MADw:10799, 10825, 11496, 4099; MADw:7399, 10290, 16165, 16664, 16672, 18471, 23124, 23397, 2370, 33891, 36075, 36076; SJRw:3681, 3701, 8919, 668, 7412, 7569, 12008, 34840, 34877, 35119, 36402, 40836, 45629, 45630, 45777, 49487, 49495, 55242. Vochysia guianensis Aubl.[V. melinonii]—BCTw:12034, 12513, 12775, 15290, 16007, 16642, 17630, 7826, 9982, 11476, 17634; MADw:14788, 19575, 21370, 23396, 2371, 25408. Vochysia inundata DuckeBCTw:16662. Vochysia laurifolia Warm—BCTw:12260, 24, 3627. Vochysia maxima Ducke-BCTw:11475, 12566, 14150, 16043, 17725. Vochysia obidensis (Huber ex Ducke) Ducke-BCTw:14147, 14148, 15210; MADW:23403. Vochysia obscura Warm._BCTw:13272. Vochysia rufescens W.A. RodriguesBCTw:16309. Vochysia speciosa Warm.-BCTw:12776. Vochysia splendens Spruce ex Warm.BCTw:16532 Vochysia surinamensis Stafleu -MADW:46658, 47571, 8461. Vochysia thyrsoidea Pohl-BCTw:14955, 15964. Vochysia tomentosa (G.Mey) DC.-BCTw:12086, 12772, 18699. Vochysia vismiifolia Spruce ex Warm.-BCTw:12033, 12656, 13969, 15093, 16053, 2862, 5015; MADw:21413, 23407, 23408; SJRw:38274, 44356. Vochysia sp.-BCTw: 83, 84, 327, 597, 2772, 3483, 3490, 3493, 3598, 4557, 4960, 5983, 6081, 8405, 9326, 9896, 11815, 12050, 13320, 13432, 13920, 13981, 16270, 19550, 19551.

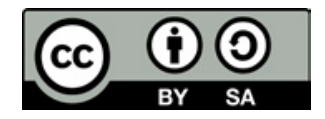

